\title{
Sosialisasi Kegiatan Penyuluhan UMKM Mewujudkan Perekonomian Masyarakat Yang Mempunyai Potensi Dan Peran Strategis Menurut Undang-Undang No. 20 Tahun 2008
}

\author{
Abdul Atsar*1, Aryo Fadlian² \\ 1,2Program Studi Ilmu Hukum, Fakultas Hukum, Universitas Singaperbangsa Karawang \\ *e-mail: abdul.atsar@staff.unsika.ac.id1aryofadlianfhunsika@gmail.com²
}

\begin{abstract}
The government has enacted Law Number 20 Year 2008 concerning Micro, Small and Medium Enterprises, but in reality there are still many people who do not yet have the interest to form MSMEs. This is due to residents not understanding the rules that apply. The method of community service is in the form of lectures. Lecturers as lecturers, and village officials as participants. Before the lecture, participants were asked to answer the pre-test questionnaire. After the material and questions and answers, participants were asked to fill in the post-test questionnaire. Based on the results of the activity it appears that increasing public understanding of MSMEs. This can be proven by various questions raised by participants and the results of the participant questionnaire assessment. Participants have understood the position of the community that has potential and strategic roles in realizing economic development, especially in Dewi Sari Village, Kec. Rengasdengklok District. Karawang, establish and manage MSMEs and so on. It is recommended that activities like this can be done routinely so that the existing MSMEs continue to grow so as to increase the income per capita of the community.
\end{abstract}

Keywords: Potential, Strategic Role, SMEs

\begin{abstract}
Abstrak
Pemerintah telah memberlakukan Undang-Undang Nomor 20 Tahun 2008 tentang Tentang Masyarakat, namun kenyataannya masih banyak masyarakat yang belum memiliki minat untuk membentuk UMKM. Hal ini disebabkan penduduk belum memahami aturan yang berlaku. Metode pengabdian kepada masyarakat ini dalam bentuk ceramah. Dosen selaku penceramah, sedangkan dan aparatur desa sebagai peserta. Sebelum ceramah, peserta diminta menjawab kuisioner pre-test. Setelah materi dan tanya jawab, peserta diminta mengisi kuisioner post-test. Berdasarkan hasil kegiatan tampak bahwa meningkat pemahaman masyarakat mengenai UMKM. Hal ini dapat dibuktikan berbagai pertanyaan yang diajukan peserta dan hasil penilaian kuisioner peserta. Peserta telah memahami tentang kedudukan masyarakat yang mempunyai potensi dan peran peran strategis dalam mewujudkan pembangunan pereknomian khususnya di Desa Dewi Sari Kec. Rengasdengklok Kab. Karawang, memndirikan dan mengelola UMKM dan sebagainya. Disarankan agar kegiatan seperti ini bisa dilakukan secara rutin agar UMKM yang ada terus berkembang sehingga menambah pendapatan perkapita masyarakat.
\end{abstract}

Kata kunci: Potensi, Peran Strategis, UMKM

\section{PENDAHULUAN}

Penyuluhan Hukum merupakan kegiatan pengabdian terhadap masyarakat guna memberikan wawasan dan informasi tentang hukum Nasional Negara Indonesia. Tujuan penyuluhan hukum. Ini adalah memberikan pemahaman kepada masyarakat. Menurut UndangUndang Nomor 20 Tahun 2008 tentang Masyarakat (UMKM):

a. Usaha Mikro adalah usaha produktif milik orang perorangan dan/atau badan usaha perorangan yang memenuhi kriteria Usaha Mikro sebagaimana diatur dalam Undang-Undang ini. Usaha Mikro memiliki kriteria asset maksimal sebesar 50 juta dan omzet sebesar 300 juta.

b. Usaha Kecil adalah usaha ekonomi produktif yang berdiri sendiri, yang dilakukan oleh orang perorangan atau badan usaha yang bukan merupakan anak perusahaan atau bukan cabang perusahaan yang dimiliki, dikuasai, atau menjadi bagian baik langsung maupun tidak langsung dari usaha menengah atau usaha besar yang memenuhi kriteria Usaha Kecil sebagaimana dimaksud dalam Undang-Undang ini. Usaha Kecil memiliki kriteria asset sebesar 50 juta sampai dengan 500 juta dan omzet sebesar 300 juta sampai dengan 2,5 miliar. 
c. Usaha Menengah adalah usaha ekonomi produktif yang berdiri sendiri, yang dilakukan oleh orang perseorangan atau badan usaha yang bukan merupakan anak perusahaan atau cabang perusahaan yang dimiliki, dikuasai, atau menjadi bagian baik langsung maupun tidak langsung dengan Usaha Kecil atau usaha besar dengan jumlah kekayaan bersih atau hasil penjualan tahunan sebagaimana diatur dalam Undang-Undang ini. Usaha Menengah memiliki kriteria asset sebesar 500 juta sampai dengan 10 miliar dan omzet sebesar 2,5 miliar sampai dengan 50 miliar.

UMKM (Usaha Mikro Kecil dan Menengah) merupakan entitas ekonomi yang tidak dapat diabaikan keberadaanya dalam proses pembangunan ekonomi di Indonesia (Ambarini, 2016). UMKM (Masyarakat) ini merupakan salah satu usaha yang berperan besar dalam menganekaragamkan produk-produk ekspor Indonesia dan menjadi andalan dalam perolehan devisa. UMKM sebagai salah satu pelaku ekonomi swasta yang memiliki kontribusi nyata bagi perekonomian negara, antara lain dari sisi jumlah, penyerapan tenaga kerja, PDB, nilai ekspor, dan investasi sudah sepatutnya mendapatkan dukungan, kesempatan, pemberdayaan, serta perlindungan hukum sebagai bentuk keberpihakan kepada pelaku usaha ekonomi rakyat. Hal ini selaras dengan ketentuan dalam konsideran huruf c Undang-Undang Nomor 20 Tahun 2008 tentang Usaha Mikro, Kecil, dan Menengah bahwa pemberdayaan UMKM diselenggarakan secara menyeluruh, salah satunya adalah perlindungan sehingga mampu meningkatkan kedudukan, peran, dan potensi UMKM dalam mewujudkan pertumbuhan ekonomi, pemerataan dan peningkatan pendapatan rakyat, penciptaan lapangan kerja, dan pengentasan kemiskinan (Masnun, 2019).

Dalam kenyataannya UMKM dapat bertahan dalam menghadapi berbagai kebijakan. Keberadaan UMKM di Indonesia sangatlah penting karena selain dapat menambah pendapatan perkapita masyarakat, UMKM juga dapat mengurangi jumlah pengangguran di Indonesia. Selain itu, melihat kenyataan bahwa sebagian besar dari jumlah UMKM di Indonesia terdapat di perdesaan, kelompok usaha tersebut sangat diharapkan sebagian motor utama penggerak pembangunan dan pertumbuhan ekonomi perdesaan, yang berarti juga mengurangi kesenjangan pembangunan antara perkotaan dan perdesaan.

UMKM memiliki peranan yang cukup kuat dalam pembangunan ekonomi di Indonesia, karena sebagian besar jumlah penduduknya berpendidikan rendah dan hidup dalam kegiatan usaha kecil baik dalam sektor tradisional maupun modern. Peranan UMKM ini menjadi bagian yang diutamakan dalam setiap perancanaan tahapan pembangunan (Susanty, 2017). UMKM diperdesaan terutama bisa berperan sebagai mendorong diversifikasi kegiatan ekonomi diluar sektor pertanian, dan ini sangat penting karena kapasitas penyerapan tenaga kerja dari sector pertanian di banyak wilayah ditanah air semakin mengecil karena banyak hal, termasuk luas lahan yang semakin sempit. Namun, hingga sekarang dibanding UMKM dinegara maju UMKM di Negara Indonesia masih lemah dalam banyak hal termasuk masih lebih berpusat pada tekhnologi rendah seperti makanan, pakaian jadi, mebel dan kerajinan.

UMKM memiliki peluang yang sangat besar untuk menjadi besar dan memiliki daya saing, jika saja memiliki manajemen yang solid. Dengan demikian diperlukan sebuah model manajemen UMKM yang dapat dijadikan pedoman oleh UMKM dalam mengelola usahanya (Bismala, 2016). Sebagian besar produk yang dihasilkan oleh sektor UMKM menyentuh sebagian besar kebutuhan dasar masyarakat. Apabila kebutuhan masyarakat ini dipenuhi oleh UMKM dari negara luar, tentu akan banyak keuntungan yang mereka raih, sehingga Indonesia hanya menjadi penonton di negeri sendiri. Hal ini juga dikhawatirkan akan banyak UMKM yang gulung tikar (Rani, 2015). Perlindungan hukum nasional terhadap UMKM sudah ada, diatur secara khusus dengan UU No. No. 20 Tahun 2008 Tentang Usaha Mikro, Kecil, dan Menengah yaitu dalam hal pemberdayaan dan pengembangan usaha, pembiayaan dan kemitraan (Kurniastuti, 2013). 
UMKM merupakan kelompok pelaku ekonomi terbesar dalam perekonomian Indonesia dan terbukti menjadi katup pengaman perekonomian nasional dalam masa krisis, serta menjadi dinamisator pertumbuhan ekonomi pasca krisis ekonomi. Maka dari itu pemerintah perlu terus mendorong pemberdayaan UMKM melalui berbagai upaya antara lain: pelatihan dan pembinaan untuk meningkatkan pengetahuan dan penguasaan teknologi bagi, penguatan permodalan. Permasalahan UMKM lain yang tidak kalah seriusnya adalah lemahnya akses informasi pasar sehingga pemasaran produk kurang mempunyai daya saing di pasar global. Sementara untuk berkiprah di pasar lokal dengan pola konsumsi masyarakat yang lebih memilih produk luar negeri menjadi salah satu faktor kurang berkembangnya UMKM. Hal ini perlu mendapatkan perhatian dari semua pihak agar UMKM tepat mampu bertahan dalam menghadapi arus persaingan global, mengingat UMKM mampu menyelamatkan perekonomian dari krisis ekonomi (Gunartin, 2017).

Permasalah yang ada di Desa Dewisari adalah kurangnya pemahaman masyarakat tentang UMKM terutama mengenai persoalan perijinan dan strategi permodalan. Berdasarkan latar belakang tersebut, maka dirasakan perlu untuk melakukan Penyuluhan hukum tentang UMKM ini adalah:

1. Dengan selesainya penyuluhan hukum ini diharapkan Masyarakat memiliki kesadaran untuk membentuk UMKM sebagai perwujudkan pembangunan perekonomian yang potensial dan strategis.

2. Warga Masyarakat mampu menjalankan UMKM dan memperoleh pemahaman tentang strategi permodalan agar UMKM yang sudah ada lebih berkembang lagi.

\section{METODE}

Adapun metode pelaksanaan kegiatan Pengabdian Kepada Masyarakat ini ialah penyuluhan hukum. Dengan rincian metode sebagai berikut: 1) ceramah atau penyuluhan dengan cara pemaparan mengenai Masyarakat berdasarkan Undang-Undang Nomor 20 Tahun 2008 Tentang Masyarakat; 2) Dialog interaktif, dalam hal ini peserta diposisikan sebagai subjek yang dapat memberikan ulasan terkait dengan problematika masyarakat Desa Dewi Sari Kecamatan Rengasdengklok Kab. Karawang. Dialog ini sebagai curah pendapat dari peserta untuk memperoleh masukan berupa persoalan, aspirasi, usulan, gagasan dan solusi; 3) penyebaran pertanyaan pre-test sebelum ceramah dan posttest sesudah ceramah bertujuan untuk mengukur tingkat pemahaman masyarakat mengenai UMKM berdasarkan Undang-Undang Nomor 20 Tahun 2008 tentang Usaha, Mikro, Kecil dan Menengah.

\section{HASIL DAN PEMBAHASAN}

Pemerintah mempunyai kebijakan yang jelas dalam Pembangunan UMKM, secara eksplisit UUD 1945 menekankan implementasi azas kekeluargaan (Pasal 33 ayat 1) dan penyelenggaraan perekonomian nasional yang berdasar atas demokrasi ekonomi dlm pembangunan ekonomi (Pasal 33 ayat 4). Tercermin dalam Visi Kemenkop dan UKM, yaitu: "Menjadi Kementerian yang Kredibel Guna Mewujudkan KUMKM yang Tangguh dan Mandiri sebagai Soko Masyarakat Perekonomian Nasional. Terdapat tiga tantangan besar yg perlu diantisipasi oleh ketiga wadah pelaku ekonomi, yaitu;

1. Mempertahankan pertumbuhan ekonomi dalam situasi proses globalisasi ekonomi yang makin meluas.

2. Mempercepat pemerataan yang makin mendesak mengingat 36,2 juta rakyat masih berada di bawah garis kemiskinan.

3. Memelihara kesinambungan kegiatan pembangunan yang stabil dan dinamis dalam rangka mengantisipasi kemungkinan adanya berbagai kendala yang menghambat upaya kita menjawab kedua tantangan di atas. 
Tantangan dalam pembangunan UMKM yang bersifat eksternal, yaitu:

1. Iklim usaha yang belum sepenuhnya kondusif;

2. Terbatasnya sarana dan prasarana usaha;

3. Terbatasnya akses pasar;

4. Produk UMK yang sifat lifetime-nya pendek;

5. Implikasi globalisasi ekonomi dan perdagangan bebas.

Tantangan pembangunan KUMKM yang bersifat internal antara lain adalah:

1. Kondisi obyektif SDM pelaku koperasi dan UMK yang masih rendah dan terbatas;

2. Manajemen yang tradisional;

3. Kurangnya permodalan;

4. Lemahnya jaringan usaha dan kemampuan penetrasi pasar.

Terdapat 6 (enam) tantangan yang dihadapi oleh UMKM secara khusus dalam aspek pembiayaan:

1. Undang-Undang Perbankan hanya mengijinkan badan usaha bank yang dapat menghimpun dana masyarakat sehingga tidak semua bank punya jaringan ke pedesaan;

2. Ketiadaan dasar hukum Lembaga Keuangan Mikro yang memberikan perlindungan, walaupun demikian, rintisan dasar hukum Lembaga Keuangan Mikro (LKM) telah dimulai melalui kebijakan bersama tiga menteri;

3. Pengawasan terhadap Lembaga Keuangan Mikro (LKM) masih minim;

4. Pembinaan Lembaga Keuangan Mikro (LKM);

5. Integrasi Lembaga Keuangan Mikro (LKM) ke dalam sektor keuangan.

6. Implementasi peran pemerintah dalam pengembangan keuangan mikro.

Yang menjadi kendala seseorang untuk memutuskan memulai usahanya adalah masalah yang paling mendasar, yaitu akses terhadap sumber permodalan dan semangat kewirausahaan. Para pengusaha pemula biasanya memilki persoalan dalam hal permodal, salah satu faktor penyebabnya adalah keuntungan usaha habis untuk kebutuhan konsumtif, modal usaha digunakan bukan untuk keperluan usaha dan pengusaha pemula tidak berani berhutang dan kendala Akses Sumber Permodalan, yaitu kelayakan usaha, agunan, dan legalitas usaha. Strategi mendapatkan permodalan, yaitu:

1. Mengawali usaha dengan modal sendiri (modal keluarga) untuk meminimalkan risiko;

2. Manfaat Legalitas Usaha: hampir semua sumber pembiayaan mensyaratkan hal ini;

3. Buat Rencana Bisnis, walaupun sederhana: hal ini sangat penting untuk meyakinkan pemilik modal.

Pengembangan UMKM tidak hanya menjadi tanggung jawab pemerintah pusat saja, namun juga menjadi tanggung jawab Pemerintah Daerah, berdasarkan asas desentralisasi. Salah satu tanggung jawab pemerintah dibidang regulasi adalah dengan melahirkan berbagai peraturan perundangan-undangan menyangkut dengan Undang-Undang Usaha Mikro, Kecil dan menengah. Adapun peraturan perundang-undangan tersebut adalah UU No. 20 Tahun 2008 tentang Usaha Mikro, Kecil dan Menengah dan berbagai peraturan pelaksananya seperti PP No. 17 Tahun 2013 tentang Peraturan Pelaksana Undang-Undang No. 20 Tahun 2008. Di samping aspek regulasi pemerintah RI juga telah membentuk struktur berupa lembaga yang tugas dan fungsinya membina dan mengembangkan UMKM, yaitu Kementerian Koperasi dan UKM. Sementara di tingkat daerah berdasarkan kewenangan otonomi yang dimiliki dapat membentuk Dinas Koperasi dan UMKM yang melaksanakan program kerja sesuai dengan tugas dan fungsinya masing-masing (Yusri, 2014).

Dalam pengembangan UMKM terdapat beberapa aspek kunci yang harus diperhatikan. Aspek-aspek kunci tersebut merupakan kristalisasi dari pembahasan ekonomi rakyat selama ini. 
Aspek-aspek kunci tersebut yakni pemerintah harus membantu pengembangan UMKM dalam bentuk pelayanan di bidang hukum, misalnya atas kepemilikan aset produktif (Sitorus, 2018) dan melalui penyuluhan hukum.

Setelah dilaksanakan penyuluhan hukum, maka dapat diketahui tingkat pemahaman masyarakat tentang tingkat pemahaman masyarakat, yang dilaksanakan pada aparatur desa dan masyarakat dengan jumlah 38 (tiga puluh delapan) orang. Peningkatan pemahaman masyarakat bisa dibuktikan dengan adanya berbagai pertanyaan yang diajukan peserta kepada pemateri dan hasil jawaban peserta penyuluhan (Ardiansah dkk, 2018).

Ternyata banyak terdapat temuan, diantaranya masyarakat dalam menjalankan usahanya belum memahami tentang strategi permodalan Usaha Mikro, Kecil dan Menengah, bahkan tidak memahami klasifikasi Usaha Mikro, Kecil dan Menengah sehingga masyarakat tidak memiliki akses permodalan ke BUMN ataupun pemerintah. Pemahaman masyarakat tentang Usaha Mikro, Kecil dan Menengah disebabkan belum adanya sosialisasi tentang Undang-Undang No. 20 Tahun 2008 tentang UMKM. Dalam menjalankan usahanya masyarakat juga membuat produk bahan jadi dari bahan baku seperti makanan ringan dan konveksi.

Berikut disajikan hasil pengamatan sebelum dilaksanakan penyuluhan hukum dapat dijelaskan bahwa diperoleh rata-rata nilai dari 38 (tiga puluh delapan) orang masyarakat sebesar 90\% masyarakat belum memahami masalah perizinan dan permodalan UMKM. Dari analisa tersebut, dapat gambaran bahwa pemahaman masyarakat tentang Undang-Undang Usaha Mikro, Kecil dan Menengah, sebelum dilakukan tindakan penyuluhan hukum terdapat berbagai kekurangan sehingga perlu diadakan perbaikan guna meningkatkan masyarakat tentang UMKM Berdasarkan kondisi awal tersebut, dalam Penyuluhan hukum ini maka penulis menggunakan penerapan metode ceramah dan dialog interaktif yang dapat menarik minat masyarakat dalam membentuk UMKM. Penyuluhan hukum dilakukan pada tanggal 26 Agustus 2019 dengan materi mewujudkan perekonomian masyarakat yang mempunyai potensi dan peran strategis melalui Ceramah dan Tanya jawab.

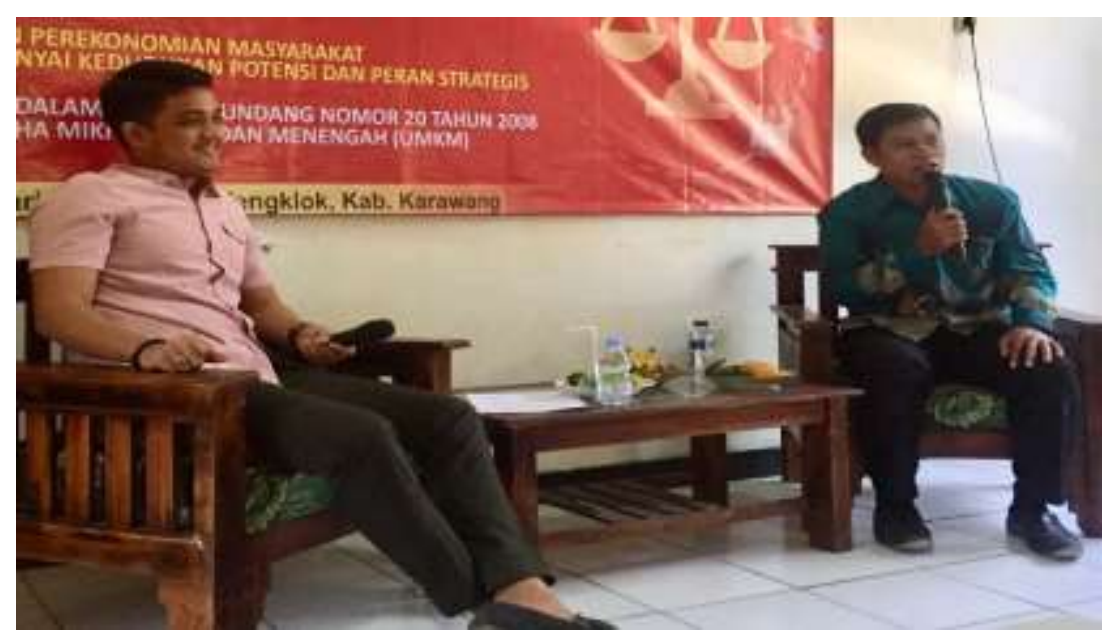

Gambar 1. Penyampain Materi Penyuluhan Hukum Tentang UMKM

Adapun kegiatan penyuluhan dilakukan pada pukul 08.00 WIB s.d 12.00 WIB. Kegiatan ini didahului dengan pembukaan oleh Kepala Desa Dewisari Kec. Rengasdengklok Kab. Karawang. Penyampaian materi dimulai Pukul 09.00 s.d 10.30 WIB Ketika masyarakat dan aparatur desa sudah memasuki ruang kelas, penulis memberi salam. 
Tabel 1. Jadwal Acara Penyuluhan Hukum Undang-Undang No. 20 Tahun 2008 Tentang UMKM

\begin{tabular}{|c|c|c|c|}
\hline NO. & WAKTU & MATERI & PEMATERI \\
\hline 1. & $07.30-08.00$ & Daftar Ulang Peserta & Panitia \\
\hline 2. & $08.00-08.30$ & Laporan Ketua Kordes & Panitia \\
\hline 3. & $08.30-09.00$ & Sambutan Pak Kepala Desa & Pak Kepala Desa \\
\hline 4. & $09.00-10.30$ & $\begin{array}{l}\text { Materi Penyuluhan Mewujudkan } \\
\text { perekonomian masyarakat yang } \\
\text { mempunyai kedudukan potensi } \\
\text { dan peran strategis. }\end{array}$ & Dr. Abdul Atsar, S.H, M.H. \\
\hline 5. & $10.30-11.00$ & Coffee Break & Tim Abdimas \\
\hline 6. & $11.00-12.00$ & Tanya Jawab & $\begin{array}{c}\text { Moderator } \\
\text { (Aryo Fadlian, S.H M.H.) }\end{array}$ \\
\hline 7. & 12.00- Selesai & Penutup & Panitia \\
\hline
\end{tabular}

Penulis mengondisikan peserta penyuluhan ke arah kegiatan penyuluhan agar kondusif dan dilanjutkan dengan apersepsi dengan melakukan tanya jawab sederhana untuk membangkitkan semangat aparat desa dan masyarakat dan menginformasikan tujuan dari diadakannya sosialisasi kegiatan penyuluhan hukum.

Berdasarkan hasil pre test atau Tanya jawab, dapat diketahui bahwa pengetahuan masyarakat tentang Usaha Mikro, Kecil dan Menengah masih sangat minim. Tingkat pengetahuan masyarakat tentang UMKM, mengalami peningkatan terdapat 27 orang peserta dengan nilai ratarata 70,00 , sebelum siklus dilaksanakan nilai rata-rata masyarakat 71,05\%. Setelah dilakukan penyluhan mengalami peningkatan sebesar 8,68 atau sebesar $28,95 \%$ dibandingkan dengan hasil sebelum siklus, hasil sebelum yaitu 62,37.

Berdasarkan hasil pengamatan kegiatan sosialisasi penyuluhan hukum melalui metode ceramah dan tanya jawab, kemudian hasil temuan pengamatan dicatat pada lembar observasi yang telah disiapkan. Berdasarkan hasil observasi perubahan pada aspek yang diamati yaitu sikap, keaktifan, wawasan, kemampuan mengemukakan pendapat dan kerjasama ada 21 orang peserta penyuluhan atau 55,26 \% masyarakat memiliki sikap, keaktifan, wawasan, kemampuan mengemukakan pendapat, kerjasama dalam kategori cukup baik dan 17 (tujuh) orang masyarakat atau 44, $74 \%$ masyarakat belum memiliki memahami materi tersebut.

Berdasarkan hasil wawancara dengan masyarakat diketahui bahwa dengan menggunakan metode ceramah dan tanya jawab, cukup dapat meningkatkan pemahaman masyarakat tentang UMKM dari hasil tanya jawab tersebut masyarakat dapat memahami materi dari banyak sumber dan dapat menyebutkan serta menjelaskan arti penting membentuk UMKM dan cara mendapatkan izin pendirian UMKM.

Sementara dari hasil diskusi dengan Penulis dengan menggunakan tanya jawab dimana Penulis menjawab pertanyaan dari peserta penyuluhan, cukup membangun aktivitas masyarakat dan kemampuan masyarakat untuk memperhatikan dan menyimak materi yang disampaikan, sehingga cukup efektif dalam meningkatkan pemahaman masyarakat tentang UMKM. 


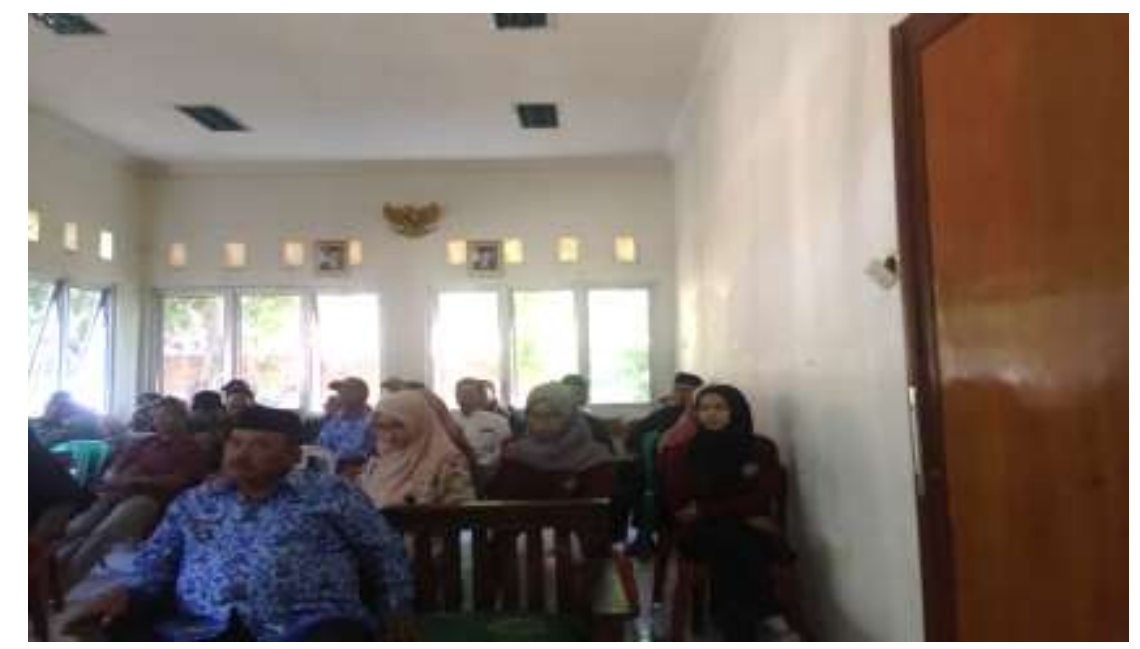

Gambar 2. Mendengarkan Materi Penyuluhan Hukum Tentang UMKM

Berdasarkan catatan lapangan yang dibuat Penulis diketahui bahwa pelaksanaan sosialisasi kegiatan Penyuluhan UMKM berlangsung secara kondusif dengan metode ceramah dan tanya jawab dimana Penulis akan memberikan kesempatan kepada peserta penyuluhan untuk berdiskusi mengenai strategi mendapatkan permodalan UMKM.

Berdasarkan hasil observasi dalam sosialisasi kegiatan Penyluhan UMKM ini belum menunjukan peningkatan pengetahuan masyarakat sesuai target yang diinginkan. Sekalipun ada perubahan namun masih banyak kelemahan, masih ada peserta yang belum memahami teknis memperoleh izin dan permodalan. Pengamatan dari aktifitas peserta penyuluhan UMKM belum tercapai sesuai target hanya 17 orang masyarakat atau 44,74\% yang memperoleh mampu menjelaskan tentang pentingnya UMKM dalam mewujudkan perekonomian keluarga dan masyarakat.

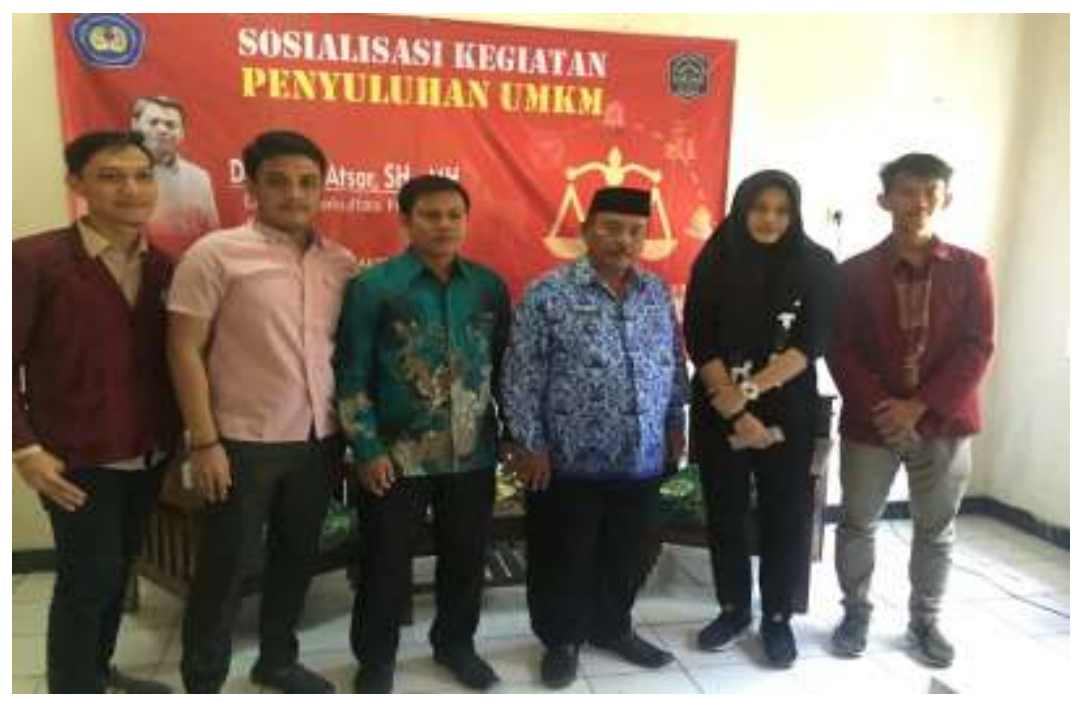

Gambar 3. Penutupan dengan Sesi Photo Bersama Dosen Pendamping LPPM, Pemateri, Kepala Desa UMKM dan Perwakilan Mahasiswa Peserta KKN

Berdasarkan hasil temuan selama sosialisasi kegiatan penyuluhan berlangsung dengan penerapan metode ceramah dan Tanya jawab, Penulis dapat melihat adanya perubahan pengetahuan dan pemahaman peserta penyuluhan. 
Tabel 2. Pemahaman Masyarakat Tentang UMKM Setelah Dilaksanakan Penyuluhan

\begin{tabular}{lcc}
\hline \multicolumn{1}{c}{ Tahapan } & Nilai Rata-Rata & Presentase Peningkatan \\
\hline $\begin{array}{l}\text { Sebelum } \\
\text { Penyuluhan }\end{array}$ & 62,37 & 23,70 \\
$\begin{array}{l}\text { Sesudah } \\
\text { Penyuluhan }\end{array}$ & 70,00 & 28,95 \\
\hline
\end{tabular}

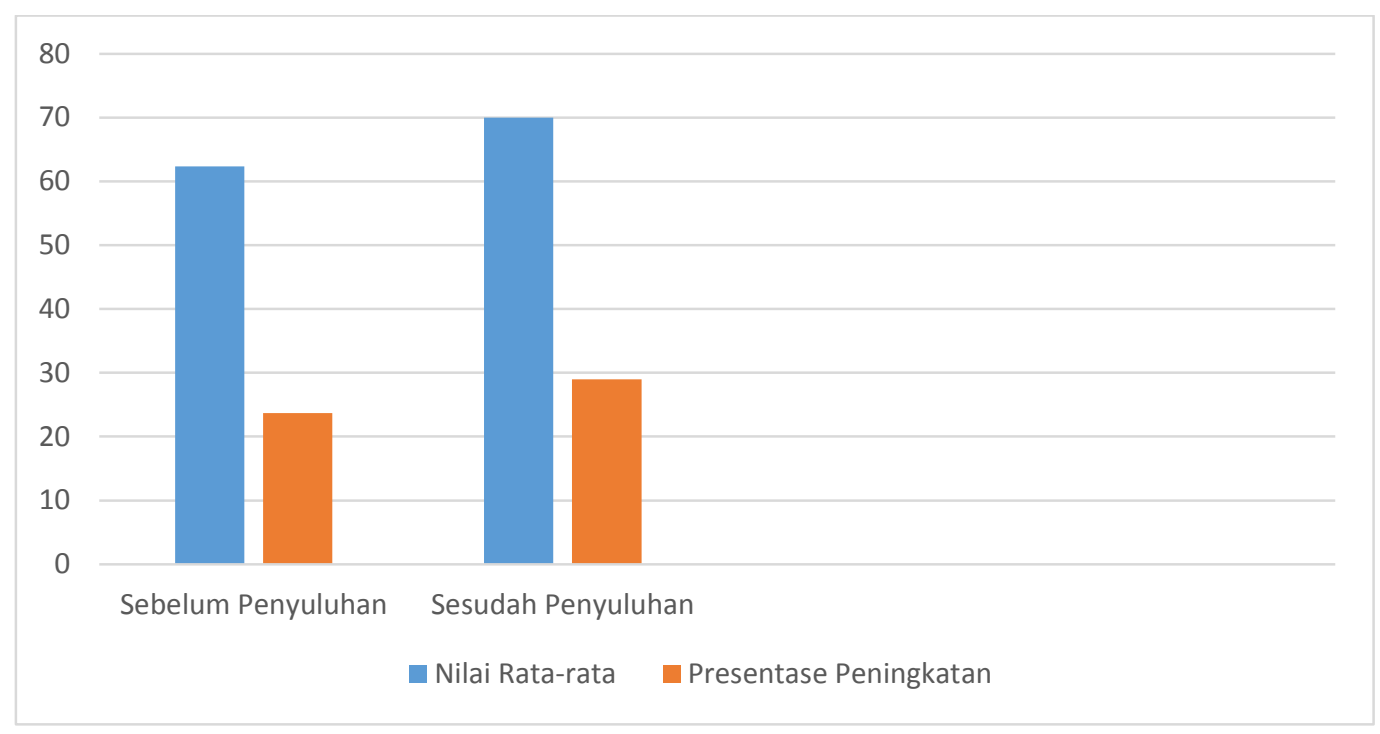

Gambar 4. Pemahaman Masyarakat Tentang UMKM Setelah Dilaksanakan Penyuluhan

Berdasarkan table dan grafik di atas dapat diketahui bahwa nilai rata-rata pemahaman masyarakat tentang hak cipta sebelum dilakukan pelatihan atau workshop yaitu 62,37 atau sekitar 57, 8\%. Setelah dilaksanakan workshop pada Siklus 1 nilai rata-rata 75,00 atau sekitar 33,23\%

\section{KESIMPULAN}

Berdasarkan permasalahan di atas maka dapat disimpulkan bahwa:

1. Tingkat kesadaran dan pemahaman mengenai potensi dan peran strategis masyarakat masyarakat Desa Dewisari Kec. Rengasdengklok Kab. Karawang dalam mewujudkan perekonomian masyarakat mengalami peningkatan;

2. Bahwa persepsi masyarakat mengalami perubahan yang siginifikan tentang pentingnya membentuk UMKM sebagai tambahan penghasilan bagi keluarga mereka;

3. Masyarakat mulai memiliki kesadaran pentingnya kerjasama antara sesama UMKM dan Pemerintah serta pemilik modal.

Yang menjadi hambatan dalam pelaksanaan mewujudkan kemajuan perekonomian masyarakat Desa Dewisari Kec. Rengasdengklok Kab. Karawang, adalah:

1. Tidak adanya sosialisasi mengenai kesadaran untuk membentuk UMKM secara periodik atau berkala;

2. Kurangnya pengetahuan kepada masyarakat tentang tata cara membentuk Usaha Kecil;

3. Belum adanya pembinaan oleh Pemerintah setempat mengenai proses perizinan pembentukan UMKM dan strategi untuk mendapatkan permodalan. 
Adapaun rekomendasi yang dapat penulis samapaikan sebagai berikut:

1. Secara kelembagaan baik dari unsur permasyarakatan tinggi khususnya yang sesuai dengan bidang keilmuanya dalam hal ini seperti ilmu hukum memberikan pengetahuan berkaitan UMKM;

2. Adanya pelatihan-pelatihan untuk mendirikan UMKM;

3. Adanya koordinasi, kerjasama dengan berbagai pihak terkait untuk menyelengaarakan kegiatan-kegiatan demi terciptanya UMKM di tengah masyarakat.

\section{UCAPAN TERIMA KASIH}

Tim Pengabdian kepada Masyarakat mengucapkan terimakasih kepada Dekan Fakultas Hukum Universitas Singaperbangsa Karawang, Ketua Lembaga Penulisan dan Pengabdian kepada Masyarakat Universitas Singaperbangsa Karawang, Camat Rengasdengklok, Kelapa Desa Dewisari, Ketua Rukun Tetangga, Ketua Rukun Warga Dewi Sari, Warga Desa Dewisari dan seluruh pihak yang telah terlibat dalam terselenggaranya kegiatan Pengabdian kepada Masyarakat ini.

\section{DAFTAR PUSTAKA}

Ade Pratiwi Susanty. (2017). Perlindungan Hukum Terhadap Kelangsungan Usaha Mikro, Kecil, dan Menengah Atas Pemberlakuan Masyarakat Ekonomi Asean, Jurnal Hukum Respublica, 16 (2), 319.

Andi Putra Sitorus. (2018). Politik Hukum Perlindungan Usaha Mikro Kecil Menengah (UMKM) Dalam Masyarakat Ekonomi ASEAN, Doktrina: Journal of Law, 1 (2), 131.

Ardiansah, Bagio Kadaryanto, Silm Oktapani. (2018). Penyuluhan Kewajiban Memiliki KTP-EL Di Desa Ujung Batu Timur Berdasarkan Undang-Undang Administrasi Kependudukan, DINAMISIA-Jurnal Pengabdian Kepada Masyarakat, 2 (2), 330.

Ari Ratna Kurniastuti. (2013). Eksistensi Perjanjian Asean-China Free Trade Area (ACFTA) dan Dampaknya Bagi Perlindungan Usaha Mikro Kecil Menengah (UMKM), Arena Hukum, 6 (2), 200.

Gunartin. (2017). Penguatan UMKM Sebagai Pilar Membangun Ekonomi Bangsa, Eduka: Jurnal Pendidikan, Hukum, dan Bisnis, 2 (2), 47.

Lila Bismala. (2016). Model Manajemen Usaha Mikro Kecil dan Menengah (UMKM) untuk Meningkatkan Efektivitas Usaha Kecil Menengah, Jurnal Entrepreneur dan Entrepreneurship, 5 (1), 21.

Muh. Ali Masnun. (2019). Reorientasi Pengaturan Pemberdayaan Hukum Usaha Mikro, Kecil, dan Menengah Melalui Hak atas Merek Kolektif, Jurnal Wawasan Yuridika, 3 (2), 223.

Nabella Puspa Rani. (2015). Perlindungan Hukum Terhadap Usaha Mikro, Kecil Menengah (UMKM) Di Kota Pekanbaru Dalam Menghadapi Masyarakat Ekonomi Asen (MEA), Jurnal Yuridis, 2 (2), 179-180.

Nur Sulistyo Budi Ambarini. (2016). Perlindungan dan Pengembangan Usaha Mikro Kecil Bidang Perikanan Sebagai Upaya Pengendalian Pencemaran Wilayah Pesisir dan Laut, Jurnal Hukum Lingkungan, 3 (1), 33.

Yusri. (2014). Perlindungan Hukum Terhadap Usaha Mikro, Kecil dan Menengah dalam Perspektif Keadilan Ekonomi, Kanun Jurnal Ilmu Hukum Yusri, 62 (XVI), 105. 